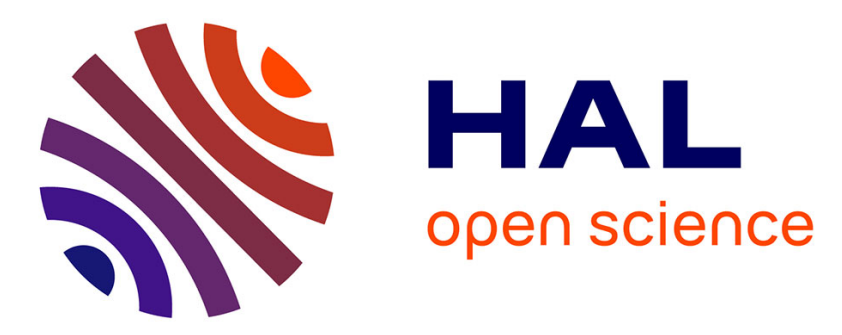

\title{
Three-dimensional tomography and rock properties of the Larderello-Travale geothermal area, Italy
}

\author{
R. de Matteis, T. Vanorio, A. Zollo, S. Ciuffi, A. Fiordelisi, Elsa Spinelli
}

\section{To cite this version:}

R. de Matteis, T. Vanorio, A. Zollo, S. Ciuffi, A. Fiordelisi, et al.. Three-dimensional tomography and rock properties of the Larderello-Travale geothermal area, Italy. Physics of the Earth and Planetary Interiors, 2008, 168 (1-2), pp.37. 10.1016/j.pepi.2008.04.019 . hal-00532146

\section{HAL Id: hal-00532146 \\ https://hal.science/hal-00532146}

Submitted on 4 Nov 2010

HAL is a multi-disciplinary open access archive for the deposit and dissemination of scientific research documents, whether they are published or not. The documents may come from teaching and research institutions in France or abroad, or from public or private research centers.
L'archive ouverte pluridisciplinaire HAL, est destinée au dépôt et à la diffusion de documents scientifiques de niveau recherche, publiés ou non, émanant des établissements d'enseignement et de recherche français ou étrangers, des laboratoires publics ou privés. 


\section{Accepted Manuscript}

Title: Three-dimensional tomography and rock properties of the Larderello-Travale geothermal area, Italy

Authors: R. De Matteis, T. Vanorio, A. Zollo, S. Ciuffi, A. Fiordelisi, E. Spinelli

PII: $\quad$ S0031-9201(08)00085-X

DOI: $\quad$ doi:10.1016/j.pepi.2008.04.019

Reference: $\quad$ PEPI 4936

To appear in: $\quad$ Physics of the Earth and Planetary Interiors

Received date: $\quad 16-5-2007$

Revised date: $\quad 27-2-2008$

Accepted date: $\quad$ 29-4-2008

Please cite this article as: De Matteis, R., Vanorio, T., Zollo, A., Ciuffi, S., Fiordelisi, A., Spinelli, E., Three-dimensional tomography and rock properties of the LarderelloTravale geothermal area, Italy, Physics of the Earth and Planetary Interiors (2007), doi:10.1016/j.pepi.2008.04.019

This is a PDF file of an unedited manuscript that has been accepted for publication. As a service to our customers we are providing this early version of the manuscript. The manuscript will undergo copyediting, typesetting, and review of the resulting proof before it is published in its final form. Please note that during the production process errors may be discovered which could affect the content, and all legal disclaimers that apply to the journal pertain. 
Three-dimensional tomography and rock properties of the Larderello-Travale geothermal area, Italy

De Matteis R. ${ }^{1}$, Vanorio T. ${ }^{2}$, Zollo A. ${ }^{3}$, Ciuffi S. ${ }^{4}$, Fiordelisi A. ${ }^{4}$, Spinelli E. ${ }^{4}$

${ }^{1}$ Dipartimento di Studi Geologici ed Ambientali, Università del Sannio, Benevento, Italy

${ }^{2}$ Department of Geophysics, Stanford University, Stanford, CA, USA

${ }^{3}$ Dipartimento di Scienze Fisiche, Università di Napoli Federico II, Napoli, Italy

${ }^{4}$ ENEL GEM - Geothermal Production, Pisa, Italy 


\section{Abstract}

2

3 In a geothermal area, a detailed knowledge of the three-dimensional velocity structures aids the

4 management of the field and the further development of the geothermal source. Here, we present a

5 high-resolution study of the three-dimensional S-wave velocity structures from microearthquake

6 travel times for the Larderello-Travale geothermal field, Italy. We have also deduced the Vp/Vs and

$7 \quad \mathrm{Vp} *$ Vs parameters for this area to emphasize the deep variations in the physical rock properties due

8 to fluid content and porosity. Furthermore, effective porous medium modelling has been performed

9 for site-relevant lithologies, to improve our interpretation of the results in terms of rock physics

10 signatures. This has allowed us to estimate the variation range of the seismological parameters

11 investigated, as well as their sensitivity for suitable rock under specific physical conditions. Low

$12 \mathrm{Vp} / \mathrm{Vs}$ anomalies, arising from a lower $\mathrm{Vp}$ compared to $\mathrm{Vs}$, dominate the geothermal field of

13 Larderello-Travale. These have been interpreted as due to steam-bearing formations. On the

14 contrary, analysis of $\mathrm{Vp} * \mathrm{Vs}$ images provides information on the relative changes in rock porosity at

15 depth. Comparison of tomographic section images with previously interpreted seismic lines

16 suggests that the reflective 'K-horizon' delineates a transition between zones that have different

17 porosities or crack gatherings. The 'K-horizon' also lies on low $\mathrm{Vp} / \mathrm{Vs}$ anomalies, which suggests a

18 steam saturation zone, despite the reduced porosity at this depth.

21 Keywords: P- and S-wave velocity, seismic tomography images, rock properties, geothermal field. 
3 The steam-dominated geothermal field of Larderello-Travale was used for the first commercial

4 production of electricity, and which came online in 1913. Enel-Geothermal Production, the

5 ENEL Unit involved in the development of geothermal resources, has drilled more than 200

6 wells in this area, down to maximum depths of about $4.0 \mathrm{~km}$ below sea level, in order to exploit

7 the steam reservoirs. The whole geothermal area is about $400 \mathrm{~km}^{2}$ and has a production of more

8 than $1,000 \mathrm{~kg} / \mathrm{s}$ of superheated steam, with a running capacity of about $700 \mathrm{MW}$ (Cappetti and

9 Ceppatelli, 2005).

10 Since this area has been under development for the generation of electric power, it has been the

11 target of many geophysical studies (for review, see Minissale, 1991) that have highlighted the

12 relatively shallow structure of the area (up to $4 \mathrm{~km}$ ). Seismic reflection lines have contributed to

13 investigations into the deeper structure of the field by showing the presence of a discontinuous

14 reflector (between $3 \mathrm{~km}$ and $8 \mathrm{~km}$ in depth), referred to as the ' $K$ horizon' in the literature (Batini

15 et al., 1978; Batini et al., 1985; Batini and Nicolich, 1985; Cameli et al., 2000; Brogi et al., 2003).

16 More recently, three-dimensional (3-D) seismic surveys have been carried out with a view to

17 improving the location of deep drilling targets (Cappetti et al., 2005).

18 One of these deep structure investigations of the Larderello-Travale geothermal field has used

19 high resolution 3-D tomographic inversion of microearthquake P-wave travel times (Vanorio et

20 al., 2004). Results from this study have shown the presence of a deep high P-wave velocity

21 structure. This structure follows the ' $K$ horizon' with a convex shape that deepens towards the 22 north-eastern and the south-eastern sides of the field. The ' $K$ horizon' lies within the lower P-

23 wave velocity zone, just above both the high-velocity structure and the earthquake locations. A 24 reliable location of the earthquakes showed that the hypocentres thicken in a narrow zone 
1 between the ' $K$ horizon' and the deep high-velocity structure revealed by P-wave velocity

2 tomography. Together with geological and geophysical evidence collected by previous studies,

3 these findings have led to the hypothesis that the ' $K$ horizon', which lies just on the top of the

4 high-velocity structure, represents the seismic signature of a fractured zone containing fluids

5 under pressure.

6 Knowledge of the P-wave velocity field alone is not sufficient to be able to connect the velocity

7 changes to deep variations in physical rock properties due to fluid content and porosity. To

8 achieve this, the determination of reliable $\mathrm{S}$-wave velocities and $\mathrm{Vp} / \mathrm{Vs}$ and $\mathrm{Vp} * \mathrm{Vs}$ models is

9 crucial to differentiate cases that remain ambiguous using P-wave velocity information alone. For

10 instance, Prasad (2002) and Dvorkin et al. (1999) have shown that the $\mathrm{V}_{\mathrm{P}} / \mathrm{V}_{\mathrm{S}}$ ratio allows the

11 differentiation of a low P-wave velocity due to overpressure or to the presence of gas. The

12 present study has used the same dataset provided by Enel for the above-mentioned tomographic

13 inversion (Vanorio et al., 2004), and it has been addressed to image a 3-D S-wave velocity model

14 of the Larderello-Travale field through a tomographic inversion of microearthquake S-wave

15 travel times.

16 To improve the effectiveness of this interpretation, the sensitivities of the seismological

17 parameters investigated have been estimated for site-relevant rocks under specific physical

18 conditions. Theoretical rock physics signatures of these parameters have been computed by

19 effective porous medium modelling (Dvorkin et al., 1999). This cross-disciplinary approach

20 contributes to the study of the Larderello-Travale geothermal field by showing an imaging of the

21 field in terms of the $\mathrm{Vp} / \mathrm{Vs}$ ratio and $\mathrm{Vp}^{*} \mathrm{Vs}$ product, and the correlation of these to the reservoir

22 rock physical properties, such as fluid content and porosity. 
Geology and reservoir formations

3 The Larderello-Travale geothermal area is located on a structural high within the northern pre-

4 Apennine belt (Figure 1). During the late Miocene, this area experienced extensive tectonic

5 activity that resulted in a block faulting structure, with horsts and grabens and a NW-SE trend.

6 The anomalous heat flow that characterizes the Larderello area appears to be related to granitic

7 stocks emplaced during the post-orogenic phase (Abbate et al., 1970; Puxeddu, 1984). At a few

8 kilometres of depth, the temperatures that can be measured are more characteristic of medium to

9 deep crust levels. Therefore, wells dug to $4-\mathrm{km}$ depths have temperatures estimated at $450{ }^{\circ} \mathrm{C}$ at

10 their bottom.

11 Figure 2 illustrates the tectono-stratigraphic units of the area and their average velocities (Batini

12 et al., 1978; Minissale, 1991; Brogi et al., 2003). The stratigraphic sequence consists of (1) Post-

13 orogenic sediments; (2) Ligurian units with embedded ophiolite blocks; (3) Calcareous rocks

14 (Tuscan Nappe); (4) Evaporite units; (5) Limestone, quartzite and phyllites (the Monticiano-

15 Roccastrada Unit); (6) Methamorphic basement composed of phyllites and gneiss. Post-orogenic

16 sediments and Ligurian units act as the cap-rock formations in the Larderello area (Minissale,

17 1991).

18 Energy production from geothermal sources in the Larderello-Travale field started at the

19 beginning of the last century, firstly exploiting a high, fractured, super-heated steam reservoir

20 located in the carbonatic-anhydritic formations. This shallower reservoir is located within the

21 Tuscan Nappe and the upper part of the Monticiano-Roccastrada Unit, down to about $1 \mathrm{~km}$ in

22 depth. It shows pressures and temperatures that range between $0.2 \mathrm{MPa}$ and1.5 $\mathrm{MPa}$ and $150{ }^{\circ} \mathrm{C}$

23 to $260^{\circ} \mathrm{C}$, respectively (Cameli et al., 2000; Cappetti et al., 2000). At the beginning of the 1970s,

24 the decline in production within the shallow reservoir forced the exploration towards a deeper 
1 one, located in the phyllite, micaschist, gneiss and granitic bodies down to 3-4 $\mathrm{km}$ in depth. At

2 the same time, water reinjection into the shallow reservoir started as an exploitation strategy that

3 was aimed at both sustaining the reservoir pressure and increasing the steam production. This

4 deep reservoir is characterized by a pressure of about 7.0 $\mathrm{MPa}$ and temperatures that range

5 between $300{ }^{\circ} \mathrm{C}$ and $350{ }^{\circ} \mathrm{C}$ (Cappetti et al., 2000). The metamorphic basement and the overlying

6 calcareous-anhydrite formations constitute a structural high that falls into a wide negative

7 gravimetric anomaly. To reproduce this anomaly, 2-D gravimetric models require the presence of

8 low density bodies $\left(2.45 \mathrm{~g} / \mathrm{cm}^{3}\right)$, that have been interpreted as granite intrusions at depths ranging

9 between $8 \mathrm{~km}$ and $12 \mathrm{~km}$ (Barelli et al., 2000).

\section{Travel-time tomography}

13 The Larderello-Travale geothermal area is characterized by some hundreds of microearthquakes

14 per year, with magnitude in the range of $0.0-3.0$. Since 1977 , the seismic activity has been

15 recorded by a local digital network that has been altered over time due to the number and

16 locations of the seismic stations. The network is composed of 26 short-period seismometers, of

17 which only 3 have three-component sensors: Casa la Serra (CLSV), Croce di Prata (CRDP) and

18 Lago (LAGO) (Figure 3). The data used in the present study were digitized at 125 samples per

19 second.

20 Epicentre locations are spread over the whole of this exploited region, even though clusters are

21 seen in particular areas; the hypocentre depths are seen mainly down to $10 \mathrm{~km}$ in depth (Figure

22 3). We have analyzed the same dataset that was used by Vanorio et al. (2004) to retrieve the 3-D

23 P-wave velocity structure of the Larderello-Travale field. The data consist of 500

24 microearthquakes that were recorded between January 1994 and September 2000, providing 
$1 \sim 7,000$ P-wave and $\sim 4,000$ S-wave first-arrival-time readings. Typical examples of seismograms

2 of the Larderello data set with picked first S-wave arrival times are shown in Figure 4. To

3 retrieve a reliable P-wave and S-wave velocity models of the geothermal area, the P-wave and S-

4 wave first-arrival times need to be simultaneously inverted for both earthquake location and

5 velocity model parameters. Since the P-wave and S-wave arrival-time readings have different

6 qualities, both in terms of numbers and accuracy, we have preferred not to perform such a joint

7 inversion, but have instead used the S-wave travel times independently.

9 - Method

10 The tomographic inversion procedure used in this study follows the method described by Benz et

11 al. (1996) that provides for velocity structure and earthquake location. It has been successful

12 applied in several areas of the world (Okubo et al., 1997; Villasenor et al., 1998, Monna et al.,

13 2003; Zollo et al., 2003). A finite-differences technique is used to compute the travel times, by

14 solving the Eikonal equation through a complex velocity structure (Podvin and Lecompte, 1991)

15 and the least squares LSQR algorithm (Paige and Saunders, 1982) for simultaneous inversion of

16 the velocity structure and hypocentre parameters. The method uses smoothness constraint

17 equations to regularize the solution controlling the velocity variation that is allowed during the

18 inversion procedure in near cells. The approach proposed by Benz et al. (1996) solve for the S-

19 wave model and the P-wave model independently, using an iterative, linearized approach. In our

20 opinion, it is suitable for cases in which the ratio $\mathrm{Np} / \mathrm{Ns}$ (with $\mathrm{Np}$, Ns the numbers of $\mathrm{P}, \mathrm{S}$ time

21 readings respectively) is high and the uncertainty on the S-wave readings is larger than $\mathrm{P}$

22 uncertainty. In effect, the $\mathrm{Vp}$ model will be constrained by $\mathrm{P}$ data that are more numerous and of 
1 better quality, and the best Vs model will be searched by a local inversion method using the best

2 Vp model as the reference model.

3

$4 \quad$ - Data selection, starting model and model parameterization

5 From the initial data set, and as in Vanorio et al. (2004), we selected earthquakes with at least 10

6 phases read and characterized by weight $\leq 2$ and $\leq 3$ for the P-wave and S-wave arrival times,

7 respectively, an azimuthal gap $<180$ degrees, and RMS residuals $<0.5 \mathrm{~s}$. The final dataset used

8 for the inversion consisted of 400 well-located earthquakes, providing $\sim 3,000$ S-phase first-

9 arrival times.

10 The best initial S-wave velocity model was derived from the 3-D tomographic P-wave velocity

11 model (Vanorio et al., 2004) by choosing an appropriate Vp/Vs ratio, as described below. For

12 each event, P-wave and S-wave readings were selected to represent $(\operatorname{Ts}(\mathrm{i})-\operatorname{Ts}(\mathrm{j}))$ - as a function

13 of (Tp(i) - Tp(j))-pairs, where the (i) and (j) indices refer to the recording stations (Figure 5).

14 Assuming a homogeneous half space, the data should fall along a straight line with a slope equal

15 to the $V_{P} / V_{S}$ ratio. The observed $(T p(i)-T p(j))$ and $(\operatorname{Ts}(i)-T s(j))$ arrival-time pairs were well

16 distributed around a linear trend, where the least square best fit line provided a $\mathrm{Vp} / \mathrm{Vs}$ of 1.73

$17 \pm 0.26$ (Figure 5). As demonstrated by Chatterjee et al., (1985), geothermal areas show extremely

18 variable $\mathrm{Vp} / \mathrm{Vs}$ ratios that besides their lithology, is due to the presence of hot water at

19 temperatures and pore pressures near the water-steam transition.

20 The travel-time residuals calculated for the S-wave velocity model derived from the P-wave

21 model using a $\mathrm{Vp} / \mathrm{Vs}$ value equal 1.73 are not well distributed around zero, as we would have

22 expected. Several tests were performed to account for the variation in the range of $\mathrm{Vp} / \mathrm{Vs}$ values

23 shown in Figure 5. The travel-time residuals illustrated in Figure 6 that were obtained for 3 
1 different values of $\mathrm{Vp} / \mathrm{Vs}$ highlight that a $\mathrm{Vp} / \mathrm{Vs}$ of 1.64 best minimizes the residuals of the initial

2 Vs model, whereas values of 1.73 and 1.55 underestimate and overestimate them, respectively.

3 The distribution of the stations and events allowed the investigation of a volume of $46 \times 36 \times 16$

$4 \mathrm{~km}^{3}$, with the top at $1 \mathrm{~km}$ above sea level. Trial inversions using different block sizes showed that

5 the best model parameterization was a uniform horizontal and vertical grid spacing of $1 \mathrm{~km}$ with

6 constant velocity cells. The grid spacing used to determine the 3-D velocity model does not need

7 to be the same as the grid spacing used to calculate arrival times. In fact, a smaller grid spacing of

$8 \quad 0.5 \mathrm{~km}$ was used for accurate arrival-time calculations.

$10 \quad$ - S-wave velocity structures

11 Figure 7a shows a map of the 3-D S-wave velocity structure from the surface down to $9 \mathrm{~km}$ in

12 depth arising from this study. As a comparison, the map of the 3-D P-velocity structure obtained

13 by Vanorio et al. (2004) is also shown in Figure 7b. Each layer is $1 \mathrm{~km}$ thick and the cells not

14 crossed by any ray are shown in grey. After 20 iterations, the S-wave arrival-time residuals

15 decreased by $31 \%$ from the initial arrival time RMS of $0.11 \mathrm{~s}$. Figure $7 \mathrm{c}$ shows the residuals

16 before (red) and after (blue) the tomographic inversion runs for the S-wave velocity model. The

17 histogram in Figure 7c better highlights the decreases in the residual values from the initial (red)

18 to the final (blue) values. The S-wave velocity spans a range of values between $1.8 \mathrm{~km} / \mathrm{s}$ and 3.8

$19 \mathrm{~km} / \mathrm{s}$, and shows similar patterns of P-velocity variation with depth. The retrieved P-velocity

20 values are consistent with velocities used for the interpretation of seismic reflection lines (Batini

21 et al., 1978; Brogi et al., 2003). Both the P-wave and S-wave maps show a localized low velocity

22 zone beneath the Travale area at $5-6 \mathrm{~km}$ in depth.

23 Figure 8 shows the spatial resolution of the retrieved S-wave velocity model through mapping the

24 synthetic reconstruction of checkerboard velocity models. The synthetic S-wave arrival times 
1 were computed using the source-receiver geometry of our dataset and the retrieved S-wave

2 velocity model perturbed by a checkerboard model. Different cell sizes have been tested; the

3 most stable velocity models were provided by addition of a checkerboard model characterized by

4 cells of $2 \times 2 \times 2 \mathrm{~km}^{3}$ and velocity of $\pm 0.15 \mathrm{~km} / \mathrm{s}$. The results for the S-wave velocity models

5 show that the velocity anomalies with wavelengths of the order of $2 \mathrm{~km}$ are reasonably well

6 recovered in the central part of the volume investigated, up to $7-8 \mathrm{~km}$. The resolution is poor at

7 the edges of the model and at depths below $8 \mathrm{~km}$, due to the lack of adequate ray coverage.

8 As most of the 4,000 first S- arrival time readings are picked on the vertical component records, we

9 have performed a Monte-Carlo experiment to estimate the stability of the inverse modelling using S

10 data (Raffaele et al., 2006). We have perturbed the S-wave traveltimes with random noise and

11 repeated each time the inversion. The basic idea of this test is that if we increase the noise level, the

12 results of the inversion should show an increased global misfit. If the global misfit remains about

13 constant even for a large perturbation then this means that the model is not constrained by the

14 observations. The noise level at which the global misfit starts to increase significantly from a constant

15 behaviour is a statistical indicator of the error level on data. In our Monte-Carlo experiment, the noise

16 level was varied from $0.05 \mathrm{~s}$ to $0.3 \mathrm{~s}$ and for each level we have run the test several times. RMS

17 remains almost constant with the noise level till a perturbation of about $0.2 \mathrm{~s}$ when it shows a sharp

18 increase reaching a value $20 \%$ higher of the original RMS. Assuming the error on the S-wave

19 readings to be equal to $0.2 \mathrm{~s}$, we computed for this noise level the average deviations of the S-wave

20 velocity for each node of the model which are in the order of $0.1 \mathrm{~km} / \mathrm{s}$ with the highest value equal to

$210.15 \mathrm{~km} / \mathrm{s}$. These values represent the lowest amplitude threshold for velocity anomalies as detectable

22 by $\mathrm{S}$ data, i.e. velocity differences in the tomographic images which are smaller than about $0.15 \mathrm{~km} / \mathrm{s}$

23 are likely related to the uncertainty on arrival time picking. 


\section{Rock physics modelling}

3 To interpret our seismological observations, it is advantageous to compare them either with

4 theoretical results or with observations obtained during controlled experiments. Variations in

5 seismic velocity depend on many physical conditions, so that linking them with observed

6 seismological variations in tomographic images is quite difficult. However, since those

7 conditions affect P-wave and S-wave velocities differently, cross-wise information of $\mathrm{Vp}$ and Vs

8 and of the $\mathrm{Vp} / \mathrm{Vs}$ ratio and $\mathrm{Vp} \mathrm{V}^{*} \mathrm{Vs}$ product help us to constrain the interpretation. In this section,

9 we briefly review how the physical parameters affect seismic velocity, and then we report on

10 rock physics modelling for site-relevant rock to emphasize how the comparisons between seismic

11 parameters under different physical conditions allow the interpretation to be improved.

12 Mineralogy, cracks, saturation conditions, fluid characteristics, temperature and formation

13 pressure all have roles in velocity variations (Birch, 1960; Spencer and Nur, 1976; O'Connell and

14 Budiansky, 1974; Toksöz et al., 1976; Ito et al., 1979; Christensen, 1985; Christensen and

15 Mooney, 1995; Sanders et al., 1995; Dvorkin et al., 1999). Since its mineralogy is an intrinsic

16 property of the local rock, a significant correlation between lithology and observed $\mathrm{Vp} / \mathrm{Vs}$ values

17 has been suggested (Tatham, 1982); therefore, by rule of thumb, the lithology may be more

18 fundamental than other factors that affect the velocity of rocks. However, the above-mentioned

19 physical conditions often outweigh the reference lithology type, so that theoretical and

20 experimental observations under different physical conditions constitute a further step in an

21 understanding of the inferred velocity variation. O'Connell and Budiansky (1974) and Toksöz et

22 al., (1976) showed that the presence of cracks and fractures decreases both Vp and Vs; since Vp

23 decreases slower than Vs, Vp/Vs increases. Similarly, Dvorkin et al. (1999) numerically

24 simulated the decreases in both $\mathrm{Vp}$ and $\mathrm{Vs}$, and thus the increase in $\mathrm{Vp} / \mathrm{Vs}$, due to the opening of 
1 compliant thin cracks in the rock caused by pore pressure increases. Furthermore, if pores are

2 saturated by fluids, $\mathrm{Vp} / \mathrm{Vs}$ is much lower for gas saturation (e.g. high compressible fluids) than

3 for liquid saturation (O'Connell and Budiansky, 1974; Ito et al., 1979). This observation derives

4 from the concept that fluid compressibility governs the P-wave velocity variation, while the S-

5 wave velocity remains nearly the same, driving the $\mathrm{Vp} / \mathrm{Vs}$ changes. Finally, temperature

6 influences the elastic properties of the rock, promoting in saturated rocks, fluid-phase transitions

7 that affect the bulk modulus of fluids (Ito et al., 1979) as well as melting of rocks as the

8 temperature approaches to near the solidus. Several theoretical and experimental studies (see

9 Sanders et al., 1995 for review, and Murase and McBirney, 1973) have reported that most of the

$10 \mathrm{Vp}$ and Vs changes $(\approx 80-90 \%)$ occur in a narrow temperature range near the solidus. In this

11 range, since $\mathrm{Vs}$ drops faster than $\mathrm{Vp}$, the $\mathrm{Vp} / \mathrm{Vs}$ ratio increases.

12 Controlled laboratory experiments on site-relevant rocks are not available for the Larderello-

13 Travale area. Nevertheless, to provide an estimate for the range of variation of the elastic

14 parameters investigated, as well as for their sensitivities under specific physical conditions, we

15 computed the seismic response of $\mathrm{Vp}, \mathrm{Vs}, \mathrm{Vp} / \mathrm{Vs}$ and $\mathrm{Vp} * \mathrm{Vs}$ as functions of saturation and

16 porosity. We used the effective medium theory of Dvorkin et al. (1999) to compute theoretical

17 rock P-wave and S-wave velocities as functions of porosity, pore fluid compressibility,

18 mineralogy and effective pressure $\left(\mathrm{Pe}=\mathrm{P}_{\text {confining }}-\mathrm{P}_{\text {pore fluid }}\right)$. The modelling was performed under

19 reservoir conditions of pressure and temperature, and concerns a fully steam- and water-saturated

20 calcareous-quartzite rock, to best simulate the lithology of the area. Partial saturation (mixing of

21 the two fluid phases) and patchy saturation have not been taken into account in this computation.

22 The elastic input parameters used in the computation are shown in Table 1 (Mavko et al. 1998;

23 Batzle and Wang, 1992); phase pressures and temperatures are also given. 
1 As a first step, this model uses the Hertz-Mindlin (Mindlin, 1949) contact theory to compute the

2 effective bulk $\left(\mathrm{K}_{\mathrm{HM}}\right)$ and shear $\left(\mu_{\mathrm{HM}}\right)$ modules of dry porous rock at critical porosity $\left(\Phi_{\mathrm{c}}\right)$ under a

3 given pressure (Nur et al., 1998). The critical porosity concept (Nur et al., 1998) separates the

4 mechanical behaviour of a rock into two distinct domains. For $\Phi<\Phi c$, the rock is frame

5 supported and mineral grains are load bearing; on the contrary, for $\Phi>\Phi c$, the rock simply 'falls

6 apart', becoming a suspension in which the fluid becomes the load-bearing phase. In a second

7 step, the variations in P-wave and S-wave velocities are calculated between the two end points at

8 zero porosity (matrix point) $\left(\mathrm{K}_{\mathrm{S}}, \mu_{\mathrm{S}}\right)$ and at the critical porosity $\left(\mathrm{K}_{\mathrm{HM}}, \mu_{\mathrm{HM}}\right)$, as well as between

9 the critical porosity $\left(\mathrm{K}_{\mathrm{HM}}, \mu_{\mathrm{HM}}\right)$ and at $100 \%$ porosity (i.e. fluid point). Finally, the P-wave and S-

10 wave velocities of the fluid-saturated rock are calculated using the Biot-Gasmann fluid

11 substitution equations (see Dvorkin et al., 1999, for details).

12 Figure 9a shows the theoretical computation of $\mathrm{Vp}$ and $\mathrm{Vs}$ as functions of porosity and saturating

13 fluid (steam, red; water, blue). The derived values of $\mathrm{Vp} / \mathrm{Vs}$ and $\mathrm{Vp} * \mathrm{Vs}$ are also shown. Both $\mathrm{Vp}$

14 and Vs normally decrease with porosity. Vp values are higher for the water-saturated than for the

15 steam-saturated rock, whereas Vs is not particularly sensitive to the nature of the saturating fluid.

16 Note that the shear modulus of the rock is the same whether it is dry or saturated, so the only

17 effect that pore fluids have on shear velocity is through increasing the density; this effect drives a

18 decrease in Vs in water-saturated rock. It turns out that the departure of the derived $\mathrm{Vp} / \mathrm{Vs}$ values

19 from the matrix value depends on the fluid content: it is higher for water-saturated rock and lower

20 for steam-saturated rock. Above the critical porosity, the rock behaves as a suspension and the

21 elastic parameters approach those for the fluid phase. At the highest porosity, the S-wave velocity

22 approaches zero and $\mathrm{Vp} / \mathrm{Vs}$ increases. On the contrary, Figure 9a shows that the change in $\mathrm{Vp}^{*} \mathrm{Vs}$

23 is less affected by fluid type and is instead more controlled by porosity along its entire range. 
1 In the second modelling (Figure 9b, top, right), the variations in the parameters are calculated as a

2 function of pore pressure. The starting point is rock with a porosity of $30 \%$. Increasing the pore

3 pressure leads to an opening of cracks and an increase in porosity. The approach to the 'falling

4 apart' condition (overpressure condition) determines the increase in $\mathrm{Vp} / \mathrm{Vs}$ and the decrease in

$5 \quad \mathrm{Vp} * \mathrm{Vs}$.

6

$7 \quad \mathbf{V p} / \mathrm{Vs}$ and $\mathbf{V p} * \mathbf{V s}$ images in the Larderello-Travale field

9 Images of the derived $\mathrm{Vp} / \mathrm{Vs}$ ratio and $\mathrm{Vp} * \mathrm{Vs}$ product are shown in Figure 10. Porosity has been

10 related to the velocity product $\mathrm{Vp} * \mathrm{Vs}$ in both laboratory and in-situ studies (Tatham, 1982;

11 Iverson et al., 1989). However, due to a lack of rock property data for the lithology of the

12 Larderello-Travale area, only the relative variation in $\mathrm{Vp}^{*} \mathrm{Vs}$ can be interpreted in terms of

13 fluctuations in porosity.

14 Variation in these properties and their relations with P-wave and S-wave velocities can be seen in

15 the sections reported in Figure 11, which have been overlaid with the interpreted seismic lines

16 (Brogi et al., 2003). Section 1 presented in Figure 11 passes through the seismic stations

17 Montebamboli (MBAM), Carboli (CRBE), Lago (LAGO), and Miniera (MINI) while Section 2

18 shown in Figure 11 passes through Sassetta (SASS), Lago (LAGO), Monterotondo (MDSV),

19 Cornate (CORN), Travale (TRAV), and Frosini (FROS). Low Vp/Vs anomalies dominate the

20 geothermal field of Larderello-Travale. In particular, low $\mathrm{Vp} / \mathrm{Vs}$ anomalies characterize the

21 south-west part of the area, from $1 \mathrm{~km}$ down to $4 \mathrm{~km}$ in depth near the Lago, Carboli and

22 Monterotondo zones. Deeper layers, between $6 \mathrm{~km}$ and $8 \mathrm{~km}$, show low $\mathrm{Vp} / \mathrm{Vs}$ ratios near to the

23 Miniera area. Since these anomalies derive from a lower Vp (i.e. a slight increase in Vp with

24 depth) compared to Vs, they are interpreted as deriving from the presence of steam-bearing 
1 formations. The tomographic sections show that these anomalies mainly occur beneath the Lago

2 and Miniera areas, down to $5 \mathrm{~km}$ and $8 \mathrm{~km}$ in depth, respectively (Figure 11, Section 1). On the

3 contrary, higher and sparse $\mathrm{Vp} / \mathrm{Vs}$ anomalies deriving from a higher $\mathrm{Vp}$ compared to Vs occur at

4 shallow depths (e.g. the Lago area in the sections). These zones overlie the relatively lower

$5 \mathrm{Vp} / \mathrm{Vs}$ anomalies and might indicate either condensation zones where low pressure and higher

6 porosity occur, or zones affected by water recharge. The analysis of the $\mathrm{Vp} * \mathrm{Vs}$ image suggests

7 that the reported 'K-horizon' (Brogi et al., 2003) appears to delineate a transition zone towards

8 formations with a relatively lower crack accumulation and/or porosity. Despite the reduced

9 porosity at that depth, the low $\mathrm{Vp} / \mathrm{Vs}$ anomalies still suggest steam saturation. This is based on

10 the fact that even small amounts of gas are capable of greatly reducing P-wave velocity, driving

$11 \mathrm{Vp} /$ Vs lower (Nur and Wang, 1989; Wang and Nur, 1992). Brogi et al. (2003) interpreted the K-

12 reflector as representing the top of a brittle-ductile transition, where its reflectivity arises from the

13 presence of overpressurized fluids. In the present study, we do not have evidence for a high

$14 \mathrm{Vp} / \mathrm{Vs}$ ratio indicating overpressure (Prasad, 2002; Dvorkin et al., 1999) along this zone.

15 However, due to the inherent resolution of our images, the hypothesis of the presence of

16 overpressurized fluids along the K-reflector cannot be ruled out. In fact, the only area that shows

17 a well constrained anomaly that accounts for an overpressure zone (i.e. low Vp, lower Vs, higher

$18 \mathrm{Vp} / \mathrm{Vs}$, and low $\mathrm{Vp} * \mathrm{Vs}$ ) occurs at 5-6 km beneath the Travale area (Figure 11, Section 2).

\section{Conclusions}

22 High resolution 3-D S-wave velocity structures have been presented and used in the present 23 study, along with the previously known 3-D P-wave velocity model, to map the distributions of $24 \mathrm{Vp} / \mathrm{Vs}$ and $\mathrm{Vp} * \mathrm{Vs}$ in the Larderello-Travale geothermal field. Mapping of these last two derived 
1 parameters has been used to delineate zones at predominant steam saturation and at density

2 fracture accruement, respectively. A comparison of these parameters with theoretical trends

3 derived from effective porous medium modelling has been performed to interpret the results in

4 terms of rock physics signatures.

5 1) Low $\mathrm{Vp} / \mathrm{Vs}$ anomalies dominate the geothermal field of Larderello-Travale. Since these

6 anomalies derive from a lower $\mathrm{Vp}$ compared to $\mathrm{Vs}$, they are interpreted as steam-bearing

7 formations. The Sections in Figure 11 show that these anomalies occur at depth under the Lago

8 and Miniera wells (see Section 1) and under the Lago-Monterotondo and Montieri-Travale zones

9 (see Section2);

10 2) Higher and sparse Vp/Vs anomalies (see Lago zone in Figure 11, Section 1) occur at shallow

11 depths due to the higher Vp compared to Vs, and they are characterized by low Vp*Vs. These

12 zones might be related either to condensation zones or zones affected by water recharge;

13 3) A distinctive zone that occurs from $5-6 \mathrm{~km}$ under the Travale well (Figure 11, Section 2) is

14 characterized by low Vp, lower Vs, higher Vp/Vs and low Vp*Vs. An earthquake cluster is also

15 seen at this depth. Cross-correlation of this information indicates the likelihood of an

16 overpressured zone in which the higher porosity at this depth is supported by pore fluid pressure. 


\section{References}

3 Abbate, E., Bortolotti, V., Passerini, P., Sagri, M., 1970. Introduction to the geology of the Northern Apennines in Development of the Northern Apennines geosyncline: Sedimentary Geology 4, 207-642.

Barelli, A., Bertini, G., Buonasorte, G., Cappetti, G., Fiordelisi, A., 2000. Recent Deep Exploration results at the margins of the Larderello-Travale Geothermal System. Proceedings 2000 World Geothermal Congress, Kyushu - Tohoku Japan.

Batini, F., Burgassi, P.D., Cameli, G.M., Nicolich, R., Squarci, P.,1978. Contribution to the study of the deep lithospheric profiles: deep reflecting horizons in Larderello-Travale Geothermal field. Mem. Soc. Geol. Ital. 19, 477-484.

Batini, F., Bertini, G., Giannelli, G., Pandeli, E., Puxeddu, M., Villa, I., 1985. Deep structure, age and evolution of the Larderello-Travale geothermal field. Geotherm. Res., Commun. Trans. 9, 253-259.

Batini, F., Nicolich, R., 1985. P and S reflection seismic profiling and well logging in the Travale geothermal field. Geothermics 14, 731-747.

Batzle, M., Wang, Z., 1992. Seismic properties of pore fluids: Geophysics 57, 1396-1408.

Benz, H.M., Chouet, B.A., Dawson, P.B., Lahr, J.C., Page, R.A., Hole, J.A., 1996. Threedimensional P and S wave velocity structure of Redoubt Volcano, Alaska. J. Geophys. Res. $101,8111-8128$.

Birch, F., 1960. The velocity of compressional waves in rocks to 10 kilobars. Part I. J. Geophys. Res. 65, 1083-1102. 
1 Brogi, A., Lazzarotto, A., Liotta, D., Ranalli, G., 2003. Extensional shear zones as imaged by reflection seismic lines: the Larderello geothermal field (central Italy). Tectonophysics 363, $1-2,127-139$.

Cameli, G., Ceccarelli, A., Dini, I., Mazzotti, A., 2000. Contribution of the seismic reflection method to the location of Deep fractured levels in the geothermal fields of southern Tuscany (central Italy). Proceedings 2000 World Geothermal Congress, Kyushu - Tohoku, Japan.

Cappetti, G., Passaleva, G., Sabatelli, F., 2000. Italy Country Update Report 1995-1999, Proceedings 2000 World Geothermal Congress, Kyushu - Tohoku, Japan.

Cappetti, G. and Ceppatelli, L., 2005. Geothermal power generation in Italy: 2000-2004 Update Report. Proceedings 2005 World Geothermal Congress, Antalia, Turkey.

Cappetti, G., Fiordelisi, A., Casini, M., Ciuffi, S. and Mazzotti, A., 2005. A new deep exploration program and preliminary results of a $3 \mathrm{D}$ seismic survey in the Larderello-Travale Geothermal field (Italy). Proceedings 2005 World Geothermal Congress, Antalia, Turkey

Chatterjee, S.N., Pitt, A.M., Iyer, H.M., 1985. Vp /Vs ratios in the Yellowstone National Park region, Wyoming J. Volc. Geoth. Res. 26, 3-4, 213-230.

Christensen, N.I., 1985. Measurements of dynamic properties of rocks at elevated temperatures and pressures. In Pincus, H.J., and Hoskins, E.R. (Eds.), Measurements of Rock Properties at Elevated Pressures and Temperatures. Spec. Tech. Publ.—ASTM, 869:93-107.

Christensen, N.I., Mooney, W.D., 1995. Seismic velocity structure and composition of the continental crust: A global view. J. Geophys. Res. Vol. 100 , No. B6, 9761-9788.

Dvorkin, J., Prasad, M., Sakai, A., Lavoie, D., 1999. Elasticity of marine sediments: Rock Physics Modeling. Geoph. Res. Lett., 26, 12, 1781-1784. 
1 Ito, H., DeVilbiss, J., Nur A., 1979. Compressional and shear waves in saturated rock during water-steam transition. J. Geophys. Res. 84, 4731-4735.

3 Iverson, W.P., Fahmy, B.A., Smithson, S.B., 1989. VpVs from mode-converted $P-S$ reflections.

$4 \quad$ Geophysics 54, 843-852.

5 Mavko, G., Mukerjy, T., Dvorkin, J., Rock Physics Handbook, Cambridge University Press, 61998.

7 Mindlin, R.D., 1949. Compliance of elastic bodies in contact: Trans. ASME, 71, A-259.

8 Minissale, A., The Larderello Geothermal Field: a review, 1991 Earth-Science Reviews, vol.31, 9 no.2, 133-151, Aug 1991

10 Monna, S., Filippi, L., Beranzoli, L., Favali, P., 2003. Rock properties of the upper-crust in 11 Central Apennines (Italy) derived from hygh-resolution 3-D tomography. Geophys. Res. 12 Lett, 30,7 , doi:10.1029/2002GL016780

13 Murase, T., McBirney, A.R., 1973. Properties of some com-mon igneous rocks and their melts at 14 high temperature. Bull. Geol. Soc. Am, 84, 3563-3592.

15 Nur, A., Mavko, G., Dvorkin, J., Galmudi, D., 1998. Critical porosity: A key to relating physical properties to porosity in rocks. The Leading Edge, 17, 3, 357-362.

17 Nur, A., Wang, Z., (Editors), 1989. Seismic and acoustic velocities in reservoir rocks: vol. 1: 18 Experimental studies, Society of Exploration Geophysicists, Tulsa, 405p.

19 O'Connell, R.J., Budiansky, B., 1974. Seismic velocities in dry and saturated cracked solids. J. 20 Geophys. Res., 79, 5412-5426.

21 Okubo, P.G., Benz, H.M., Chouet, B.A, 1997. Imaging the crustal magma sources beneath Mauna Loa and Kilauea volcanoes, Hawaii. Geology, 25, 10, 867-870.

23 Paige, C.C., Saunders, M.A., 1982. LSQR: An algorithm for sparse linear equations and sparse 24 least squares. ACM Trans.Math.Software, 8, 43-71. 
1 Podvin, P., Lecomte, I., 1991. Finite difference computation of traveltimes in very contrasted velocity models: a massively parallel approach and its associated tools. Geophys. J. Int. 105, 271-284.

4 Prasad, M., 2002. Acoustic measurements in sands at low effective pressure: Overpressure detection in sands. Geophysics 67, 2, $405-412$.

6 Puxeddu, M., 1984. Structure and late Cenozoic evolution of the upper lithosphere in Southwest Tuscany (Italy). Tectonophysics 101, 3-4, pp.357-382.

Raffaele, R., Langer, H., Gresta, S., Moia, F., 2006. Tomographic inversion of local earthquake data from the Gioia Tauro basin (south-western Calabria, Italy). Geophys. J. Int. 165, 167179, doi: 10.1111/j.1365-246X.2006.02872.x.

Sanders, C.O., Ponko, S.C., Nixon, L.D., Schwartz, E.A., 1995. Seismological evidence for magmatic and hydrothermal structure in Long Valley caldera from local earthquake attenuation and velocity tomography. J. Geophys. Res. 100, 8311-8326.

Spencer, J.W.Jr., Nur, A.M., 1976. The effects of pressure, temperature, and pore water on velocities in Westerly Granite. J. Geophys. Res. 81, 5 ,899-904.

Tatham, R.H., 1982. Vp/Vs and Lithology, Reprints, 50th Annual International Meeting, Society of Exploration Geophysicists, R35, 2401-2414.

Toksöz, M.N., Cheng, C.H., Timur, A., 1976. Velocities of seismic waves in porous rocks. Geophysics 41, 621-645.

Vanorio T., De Matteis R., Zollo A., Batini F., Fiordelisi A., Ciulli B., 2004. The deep structure of the Larderello-Travale geothermal field from 3D microearthquake traveltime tomography. Geophys. Res. Lett., 32, doi:10.1029/2004GL019432 
1 Villasenor, A., Benz, H.M; Filippi, L., De Luca, G., Scarpa, R., Patane, G., Vinciguerra, S., 1998. Three-dimensional P wave velocity structure of Mt. Etna, Italy. Geophys. Res. Lett. 25, no.11, 1975-1978.

4 Wang, Z., Nur, A. (Editors), 1992. Seismic and acoustic velocities in reservoir rocks. vol. 2: Theoretical and model studies, Society of Exploration Geophysicists, Tulsa, 457

6 A. Zollo, S.Judenherc, E.Auger, L.D'Auria, J.Virieux, P.Capuano, C.Chiarabba, R.de Franco, J.Makris, A.Michelini and G.Musacchio, 2003. Evidence for the buried rim of Campi Flegrei caldera from 3-d active seismic imaging, Geophys. Res. Lett. , 30, 19, doi:10.1029/2003GL018173 
Figure legends

2

3 Figure 1. Geological sketch map of the Larderello area. Inset, Italy and Tuscany map showing

4 the target location. (1), (2), (3) Cenozoic marine and continental sediments; (4) Ligurian

5 Complex; (5) Tuscan Nappes: carbonatic sequence; (6) Tuscan Nappes: basal evaporites; (7)

6 phyllites formation; (8) normal faults; (9) mineralized normal faults; (10) seismic lines; (11)

7 borehole locations (Modified from Brogi et al., 2003). Dotted box represents the area investigated

8 in this study and showed in Figure 3a.

10 Figue 2. Tectono-stratigraphic units outcropping in the Larderello area: MPQ - Cenozoic

11 sediments; TN - Tuscan Nappes: TN2, Carbonatic sequence, and TN1, basal evaporites; MRU -

12 Monticiano-Roccastrada Unit: dolostones, limestones, and quartzites (MRU3), phyllites and

13 quatzites (MRU2); micaschistes (MRU1); BA - gneiss complex; MG - magmatic intrusion

14 (modified from Brogi et al., 2003). The figure is a schematic representation of temporal 15 sedimentary sequence and does not reproduce the real thickness of units. The average velocities 16 of the formations are given on the left (Batini et al., 1978).

18 Figure 3. (a) Map showing the seismic station locations (triangles) of the ENEL permanent 19 recording network, and seismic event locations (dots) used in the present study. Casa la Serra 20 (CLSV), Croce di Prata (CRDP) and Lago (LAGO) are the 3 stations with three-component 21 sensors. 3(b) W-E section showing the depth of the hypocentres following a preliminary events 22 location. 
1 Figure 4. Typical seismograms of the Larderello data set with the $\mathrm{S}$ first arrival times and

2 relative weights are shown. Time readings have been weighted by a standard 0 to 4 coefficient

3 related to the reading errors (weights of $0,1,2,3$ and 4 were associated, respectively, to

4 uncertainties of $\leq 0.05,0.05-0.10,0.10-0.15,0.15-0.20,>0.20$ seconds).

6 Figure 5. $T s_{i}-T s_{j}$ as functions of $T p_{i}-T p_{j}$ pairs; the (i) and (j) indices refer to the recording 7 stations. The pairs refer to P-wave and S-wave reading times weighted as $<2$ (uncertainty $<0.1 \mathrm{~s}$ ) 8 and $<3$ (uncertainty $<0.2 \mathrm{~s}$ ), respectively.

10 Figure 6. Travel-time residuals calculated using S-wave velocity models obtained from different $11 \mathrm{Vp} /$ Vs values.

13 Figure 7. (a) Map of the 3-D S-wave velocity model from the surface down to $9 \mathrm{~km}$ in depth.

14 The cells not covered by rays are in grey. (b) Map of the 3-D P-wave velocity model obtained by

15 Vanorio et al. (2004). (c) Plots of arrival time residuals as a function of distance and residual 16 hystogram before (red) and after (blue) tomographic inversion runs for the S-wave velocity 17 models.

19 Figure 8. Checkerboard tests for S-wave velocity model. Checkerboard cells from the input 20 model are $2 \mathrm{~km}$ wide and correspond to a velocity anomaly of $\pm 0.15 \mathrm{~km} / \mathrm{s}$.

22 Figure 9. (a) Theoretical computations of $\mathrm{Vp}$ and $\mathrm{Vs}$ as functions of porosity and saturating fluid 23 (steam, red line; water, blue line) and derived curves for $\mathrm{Vp} / \mathrm{Vs}$ and $\mathrm{Vp} * \mathrm{Vs}$. (b) The variations in 
1 the parameters are calculated as a function of pore pressure. The elastic modules and densities of

2 the phases used as input parameters to generate these theoretical curves are given in Table 1.

3

4 Figure 10. Map of the 3-D Vp/Vs (a) and $\mathrm{Vp} * \mathrm{Vs}$ (b) structures and the earthquake locations

5 from the surface down to $9 \mathrm{~km}$ in depth. The cells not covered by rays are grey.

6

7 Figure 11. Vertical cross-sections of $\mathrm{Vp}, \mathrm{Vs}, \mathrm{Vp} / \mathrm{Vs}$ and $\mathrm{Vp} * \mathrm{Vs}$. The orientations of the 8 tomographic sections, Section 1 and Section 2, are shown in Figure 3. 
Table 1. Elastic moduli and densities of the phases used as the input parameters to generate the theoretical curves (Figure 8).

\begin{tabular}{|c|c|c|c|}
\hline Phases & K (GPa) & $\mu(\mathbf{G P a})$ & $\rho\left(\mathbf{g} / \mathbf{c m}^{\mathbf{3}}\right)$ \\
\hline Quartz $(40 \%)+$ Calcite $(60 \%)$ & 57 & 36.7 & 2.69 \\
\hline $\begin{array}{c}\text { Water } \\
\left(\mathrm{T}=200{ }^{\circ} \mathrm{C}, \mathrm{Pe}=30 \mathrm{MPa}\right)\end{array}$ & 2.2 & --- & 0.93 \\
\hline $\begin{array}{c}\text { Steam } \\
\left(\mathrm{T}=400{ }^{\circ} \mathrm{C}, \mathrm{Pe}=30 \mathrm{MPa}\right)\end{array}$ & 0.5 & --- & 0.73 \\
\hline
\end{tabular}




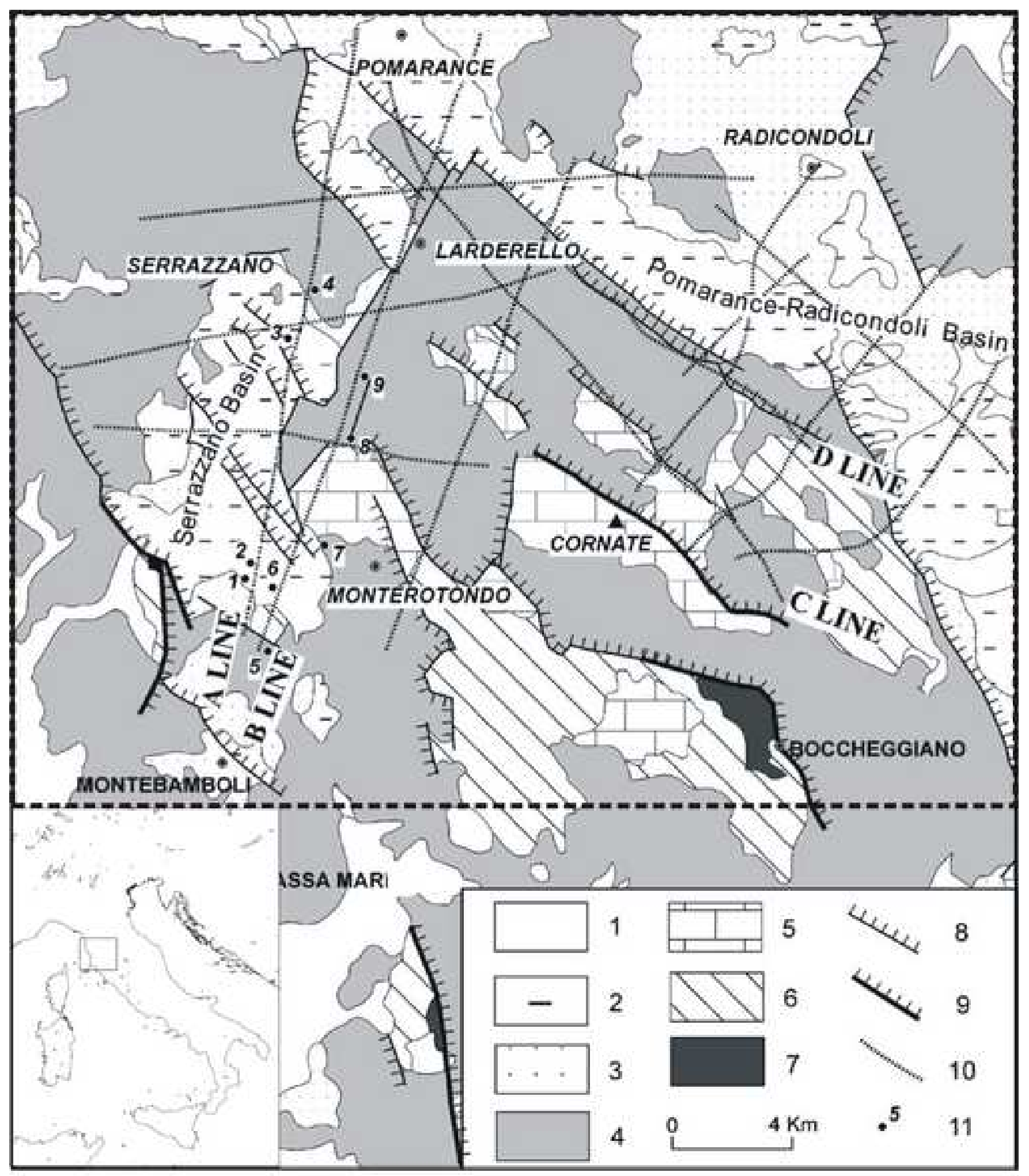

Figure 1 


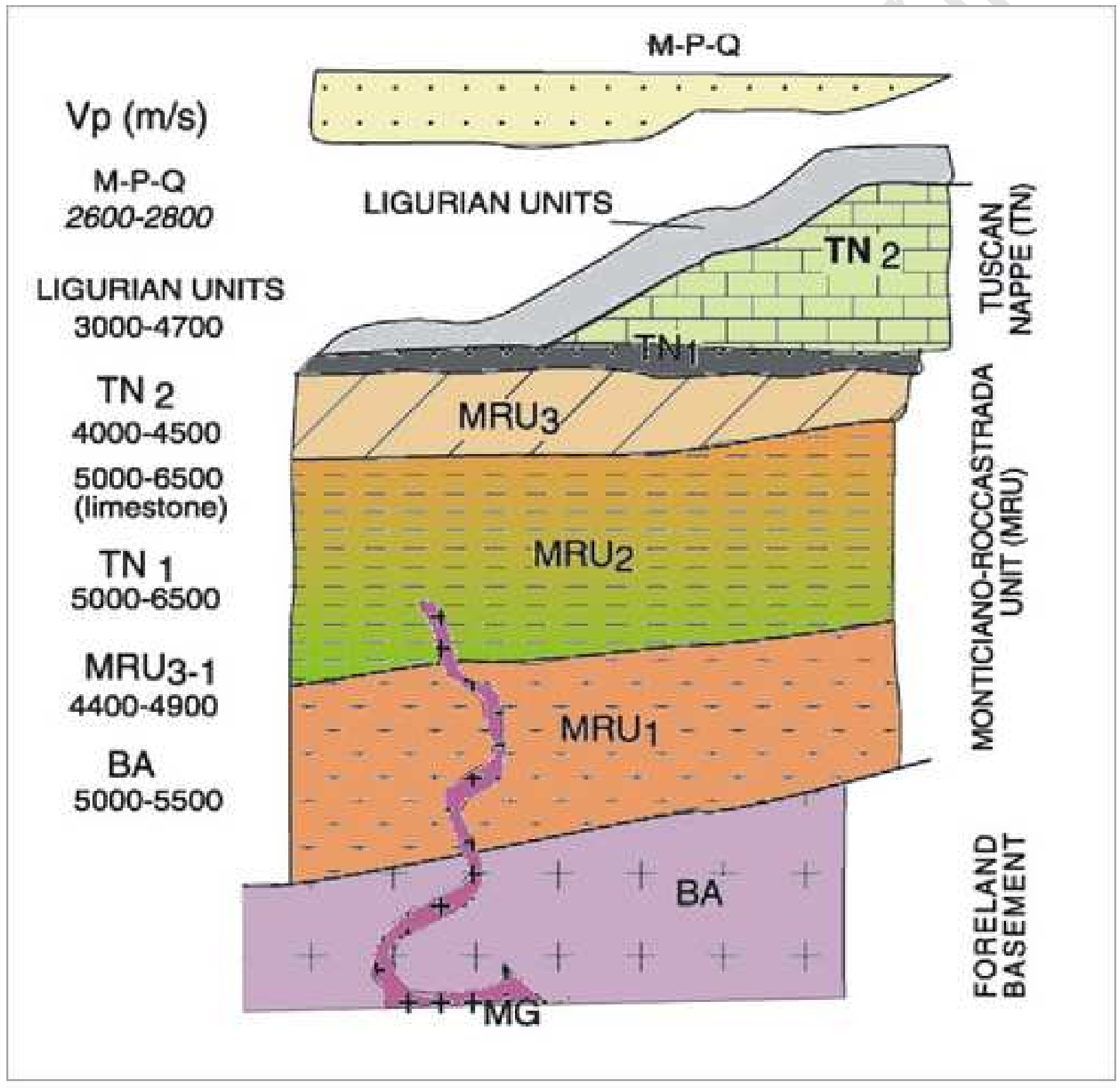

Figure 2 

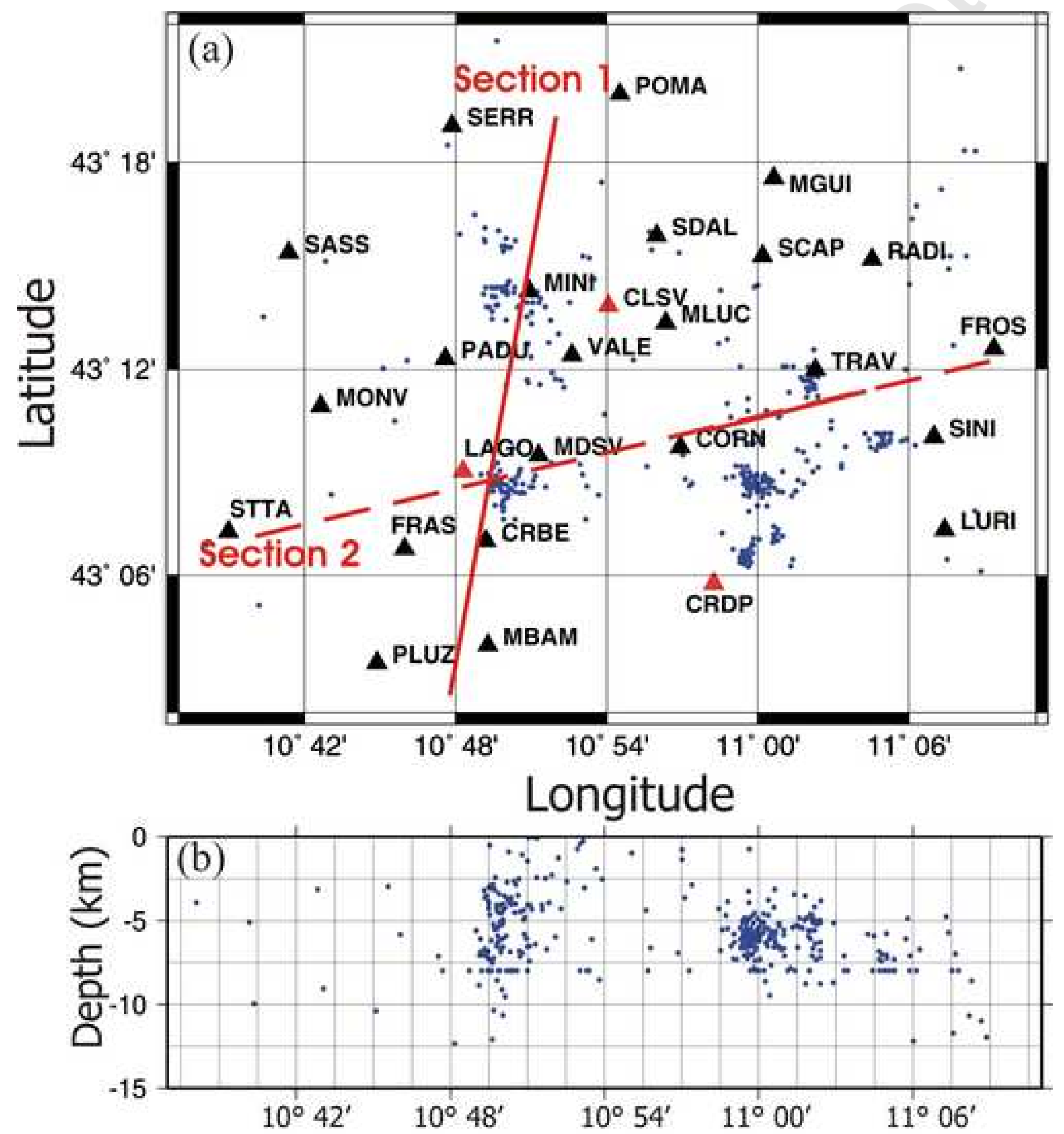

Figure 3 
Event 98-02-21 01:18:35.222

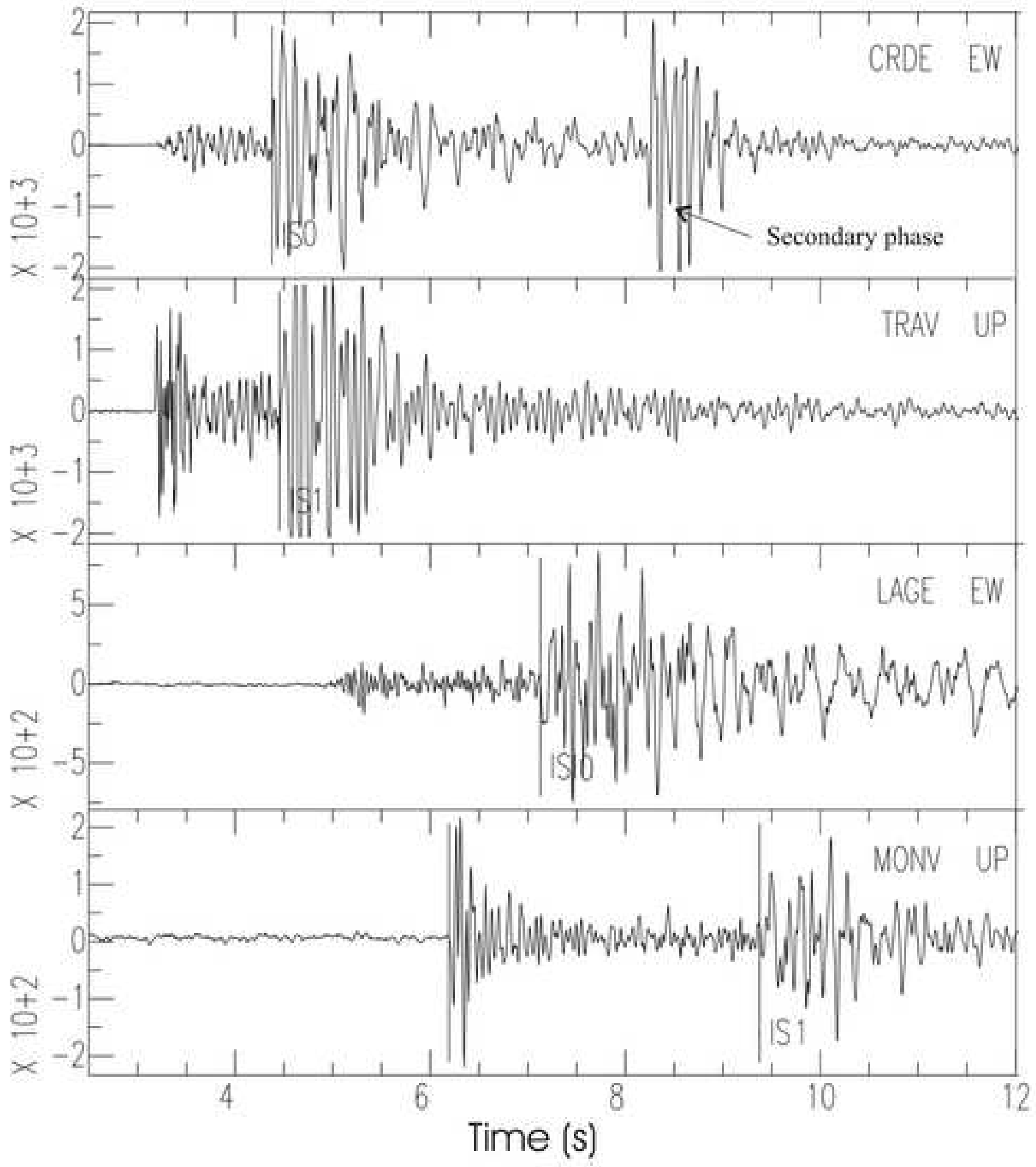

Figure 4 


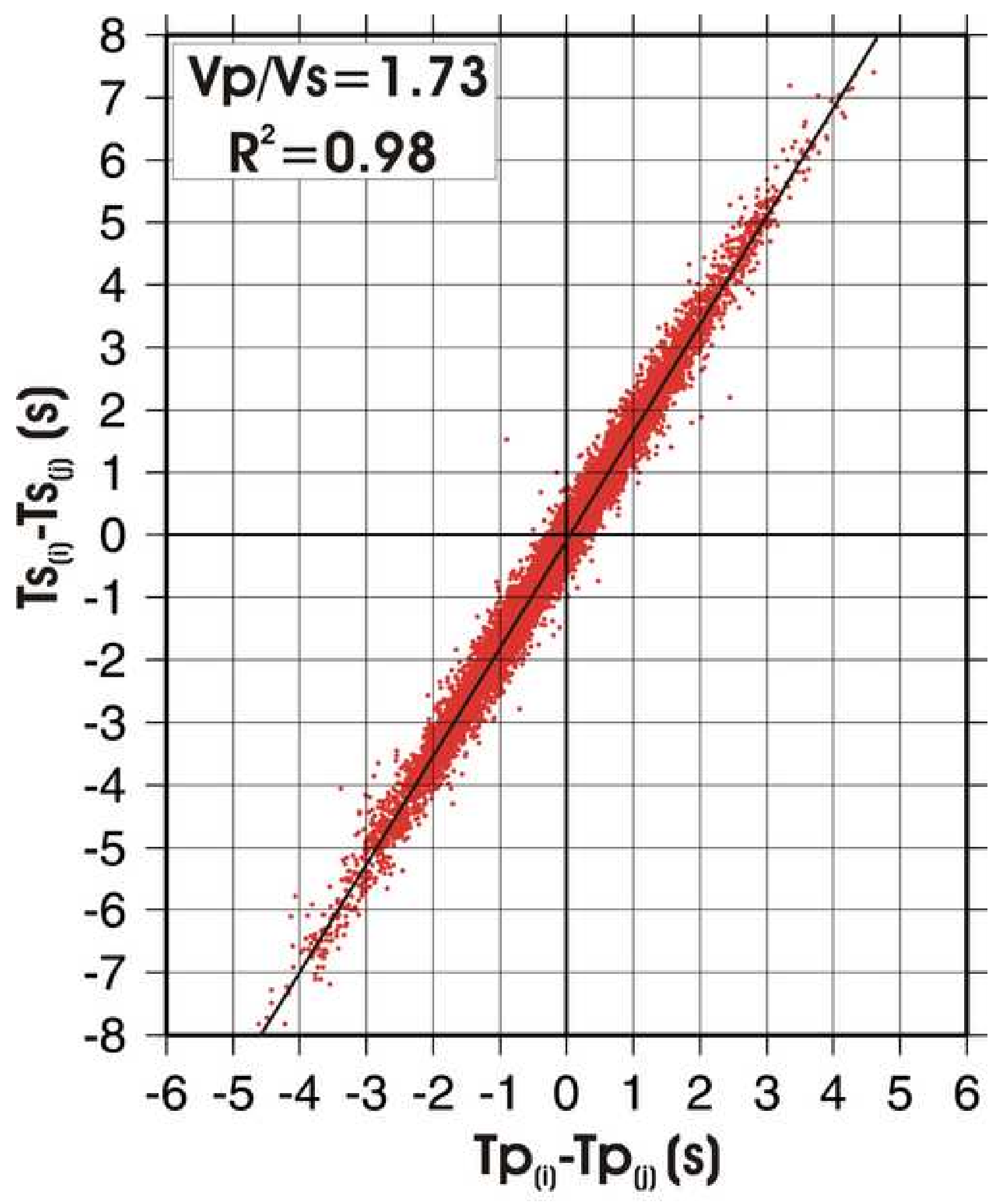

Figure 5 


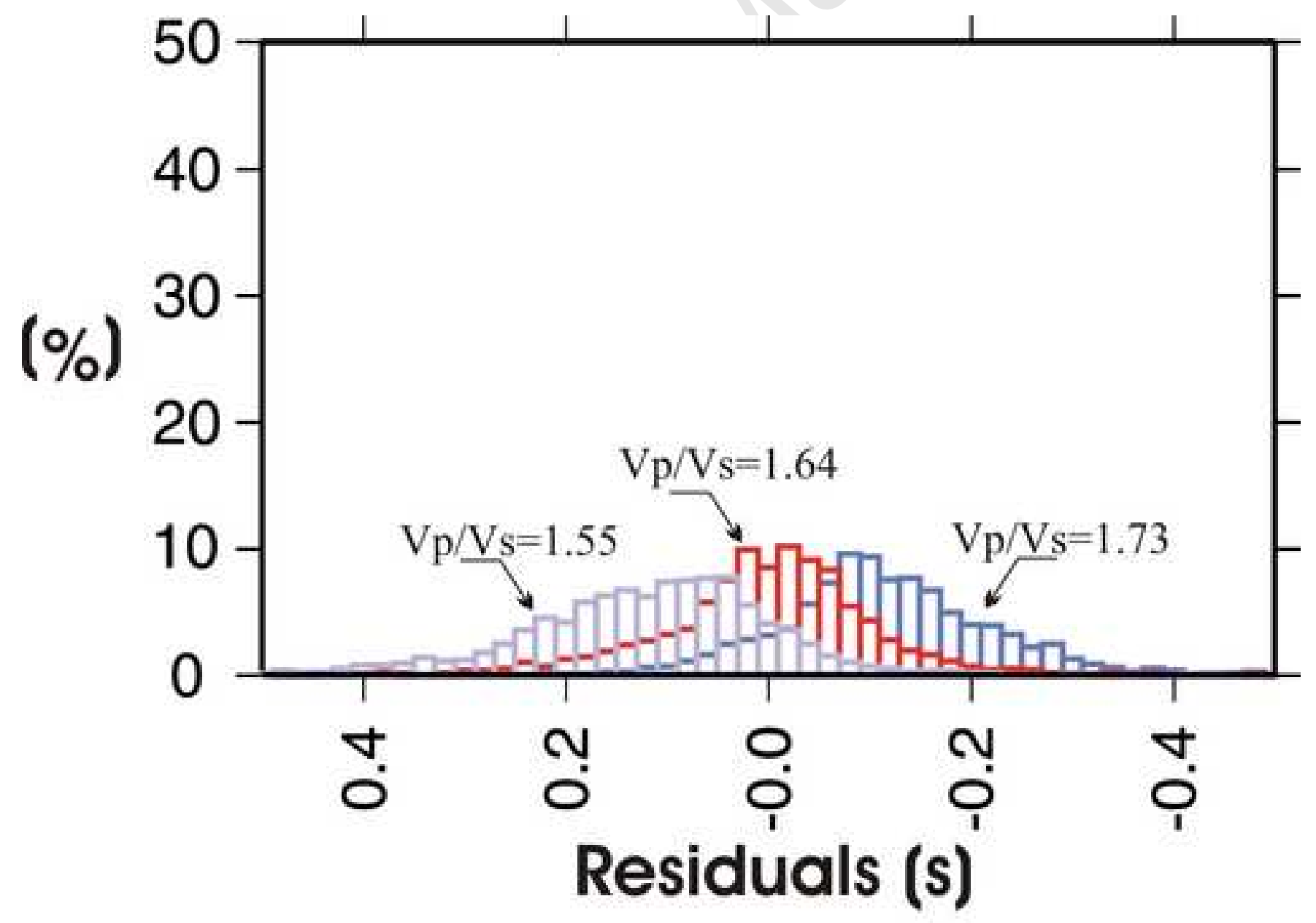

Figure 6 

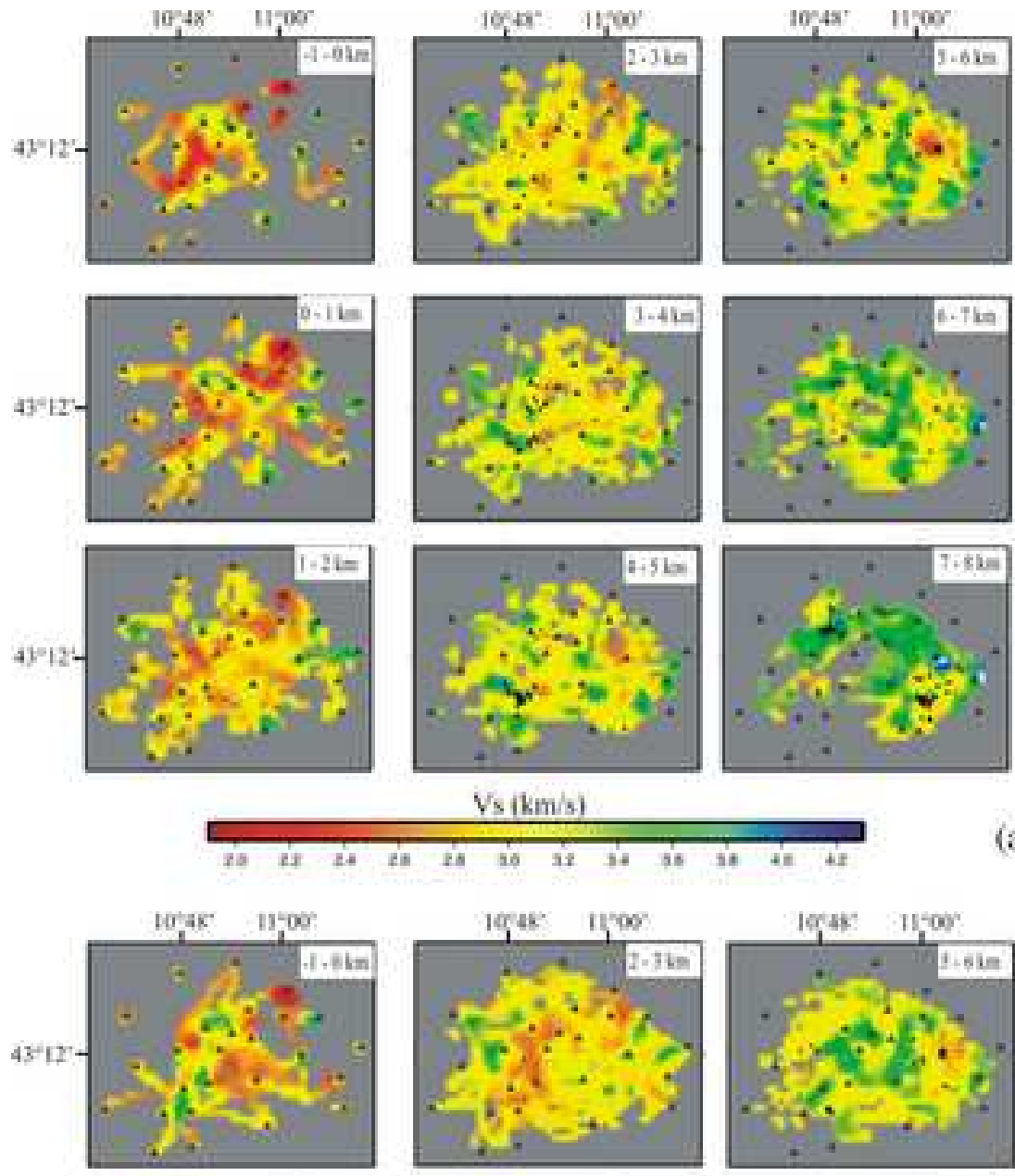

$\mathrm{Vs}(\mathrm{km} / \mathrm{s})$

(a)
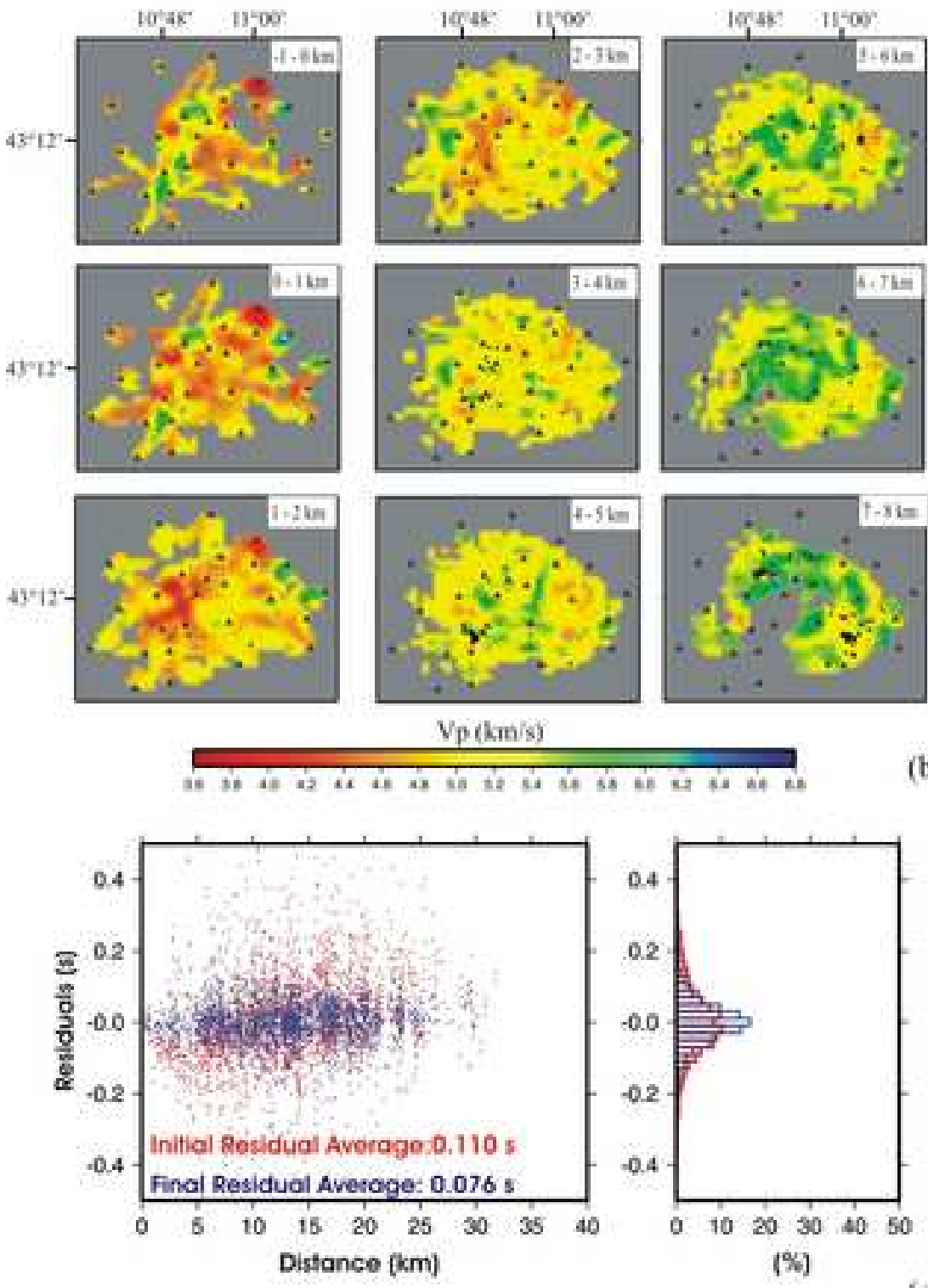

(c)

Figure 7 

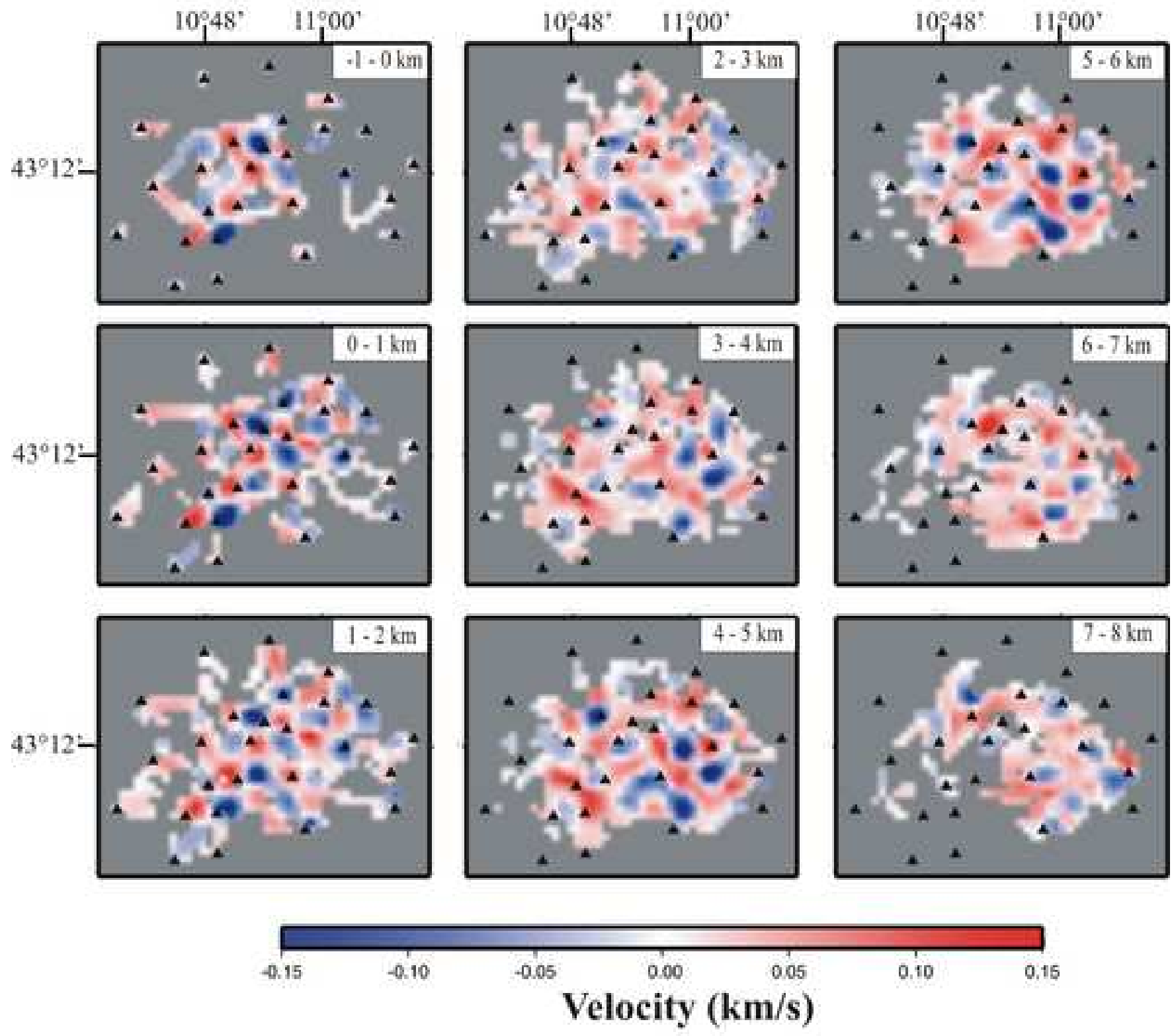

Figure 8 


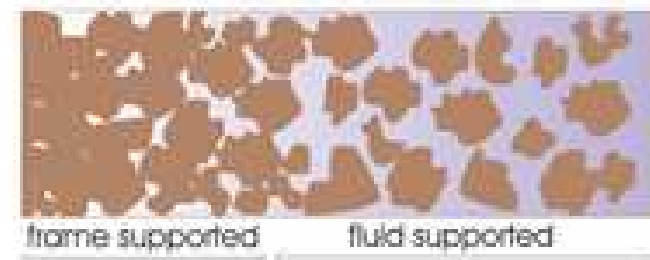

frome suppocted

$\phi$

0

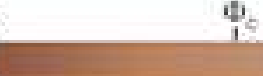

Porosity
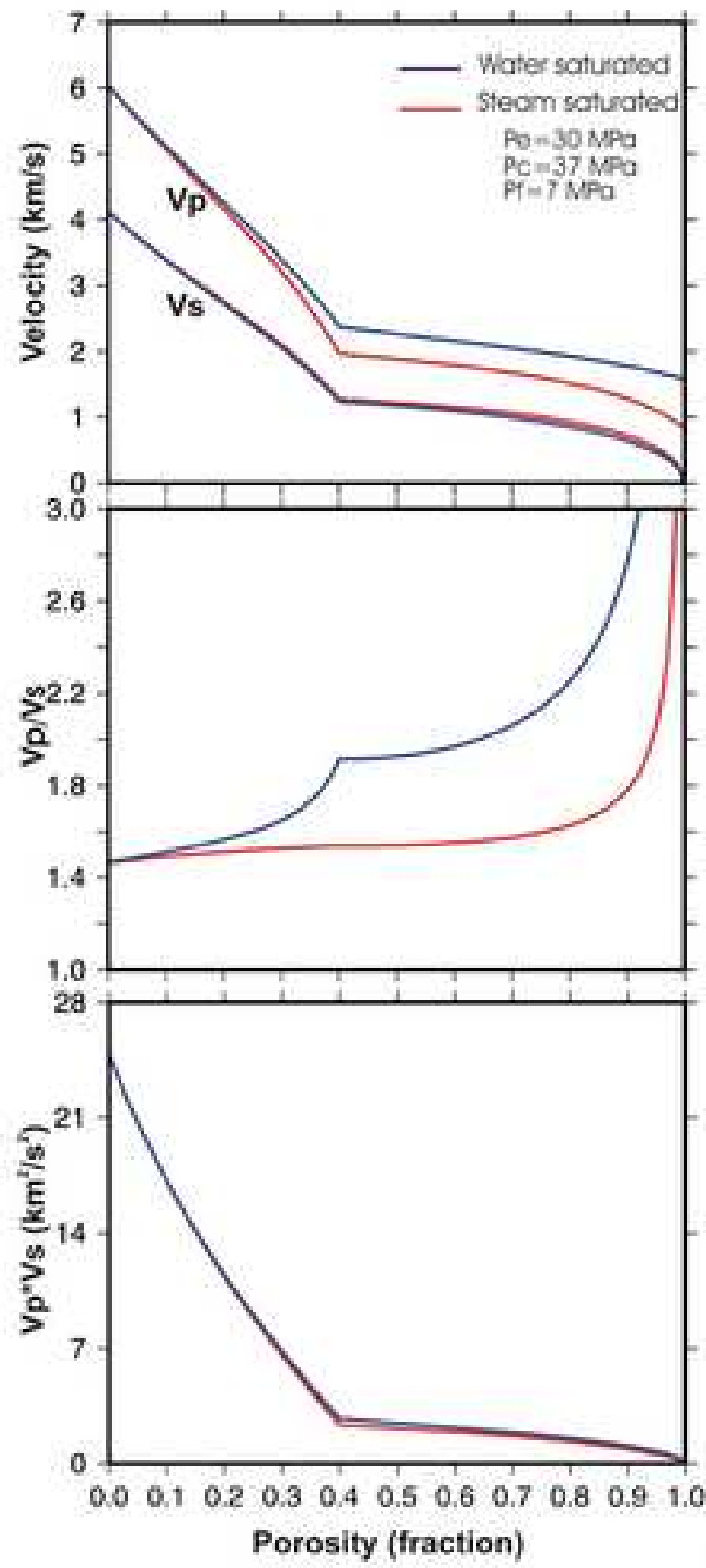

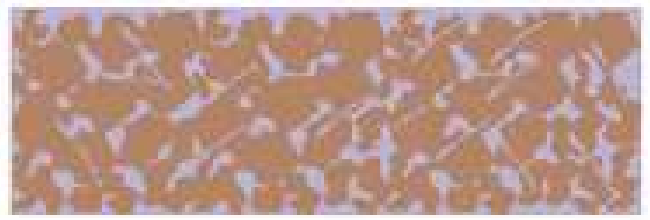

$\Phi=30 \%$ crocks opening and inciecsing potosity

Porosity

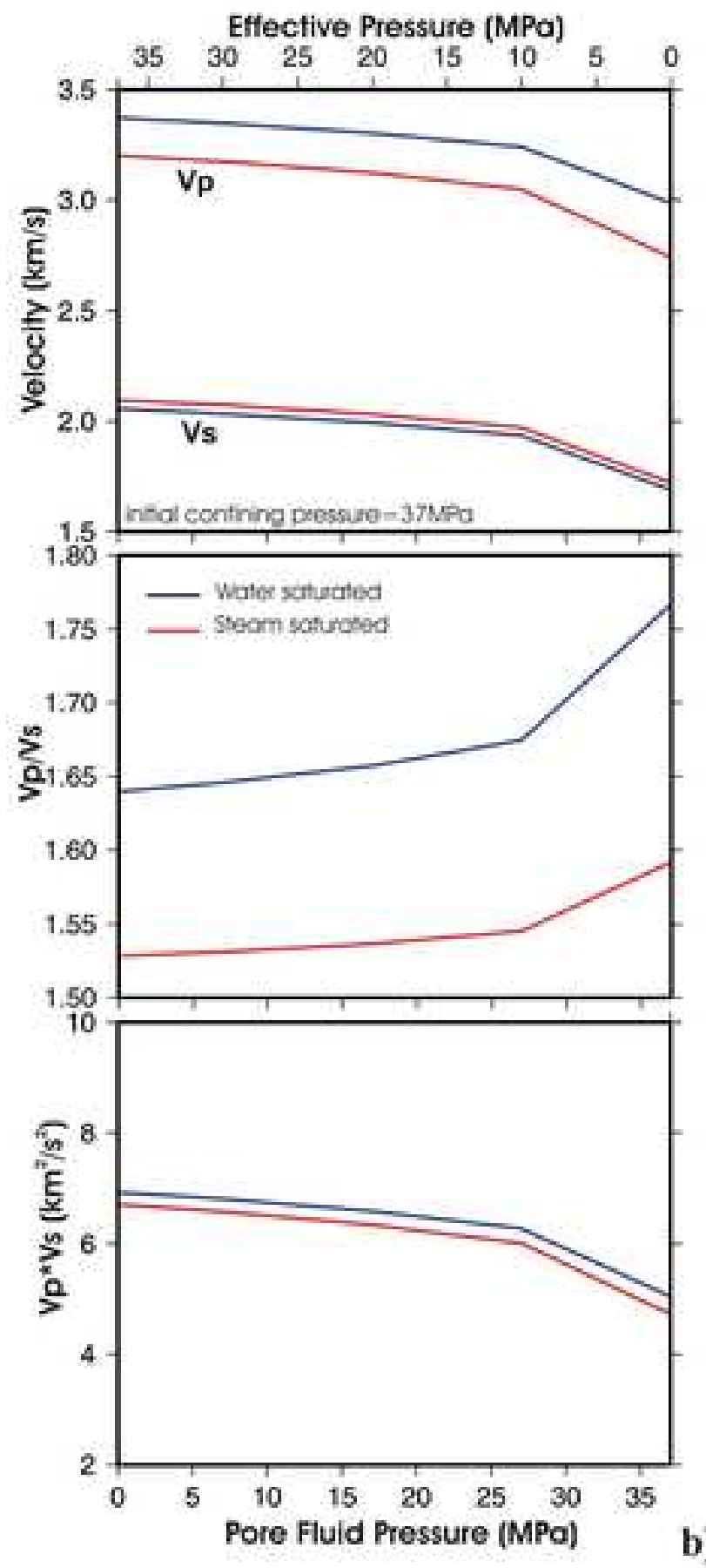

Figure 9 

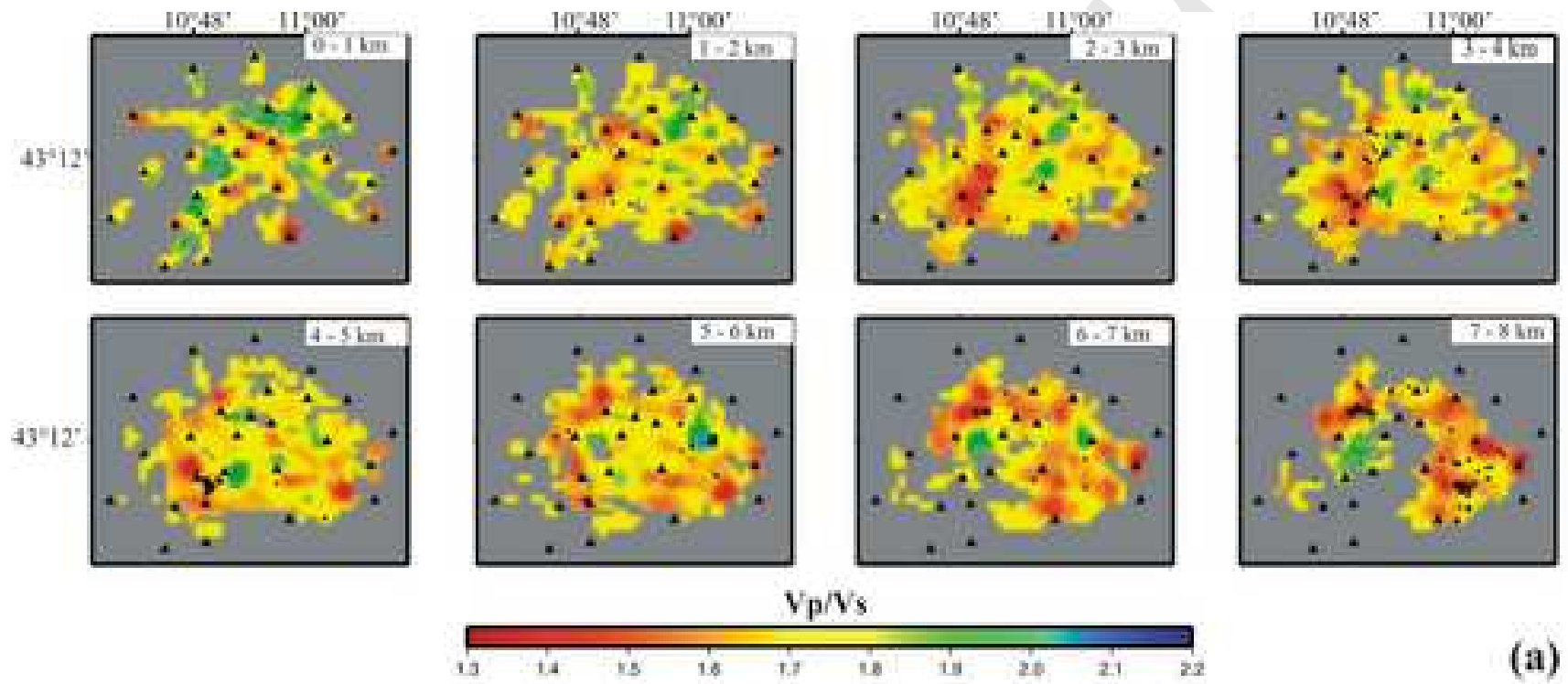

(a)
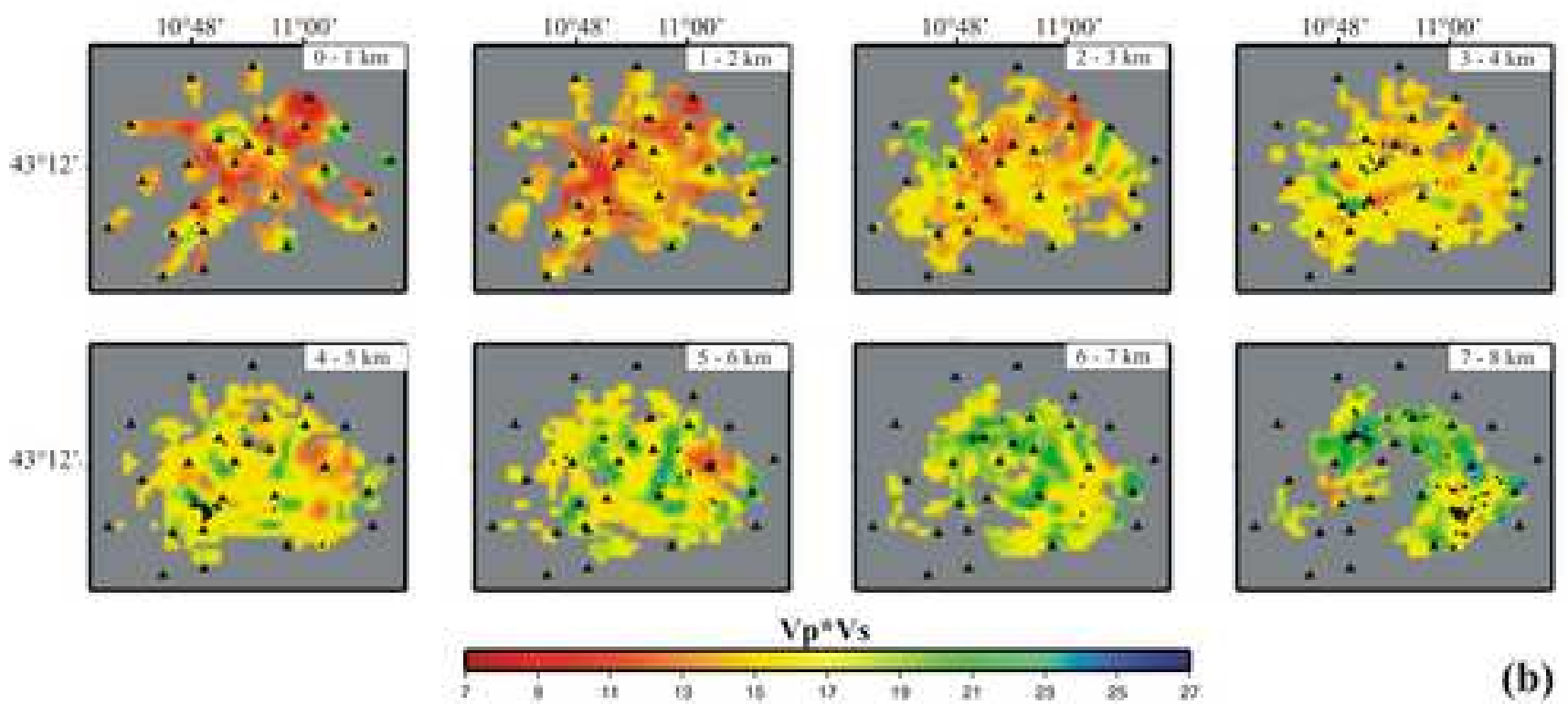

(b)

Figure 10 


\section{Section 2}

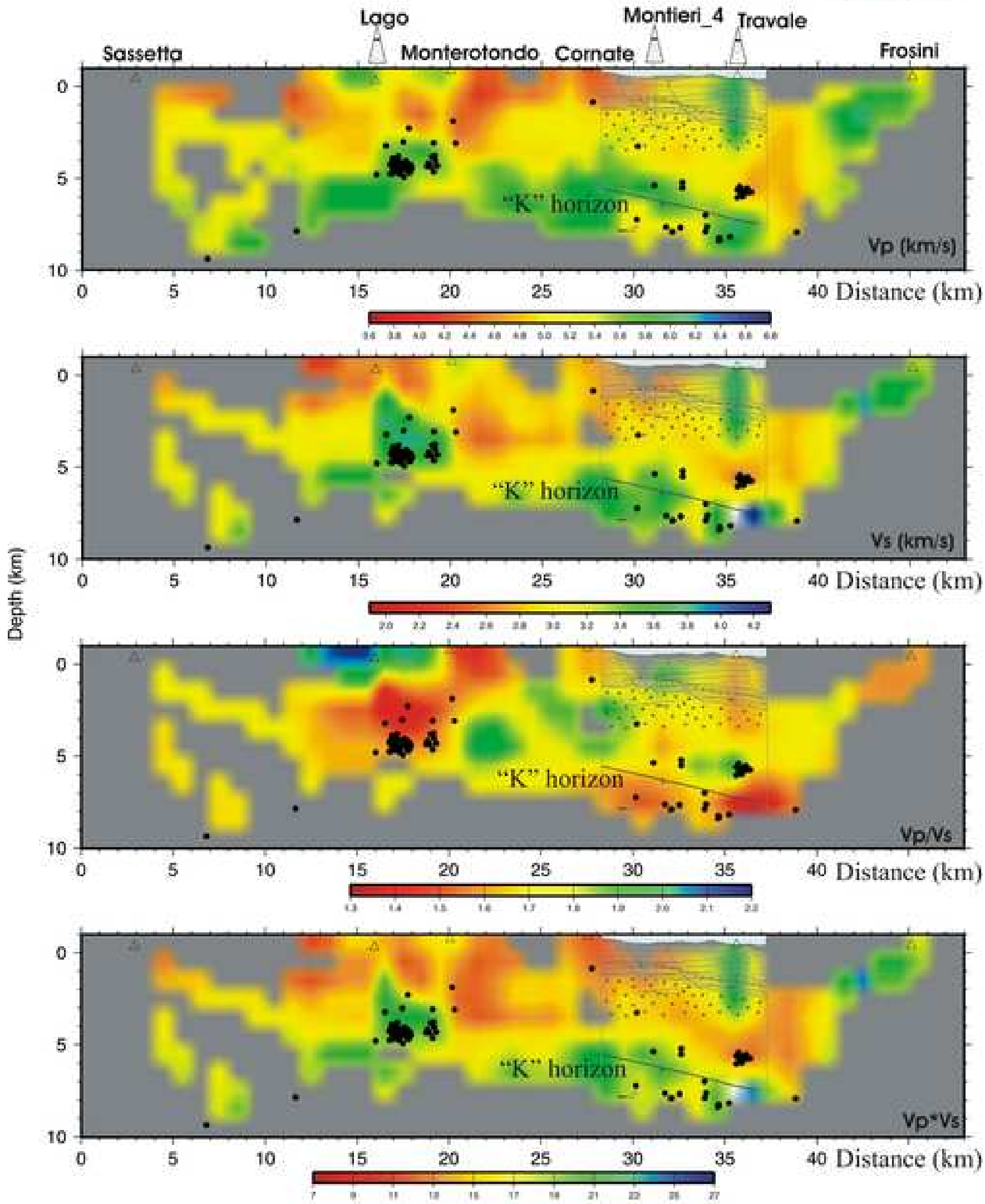

Figure 11 

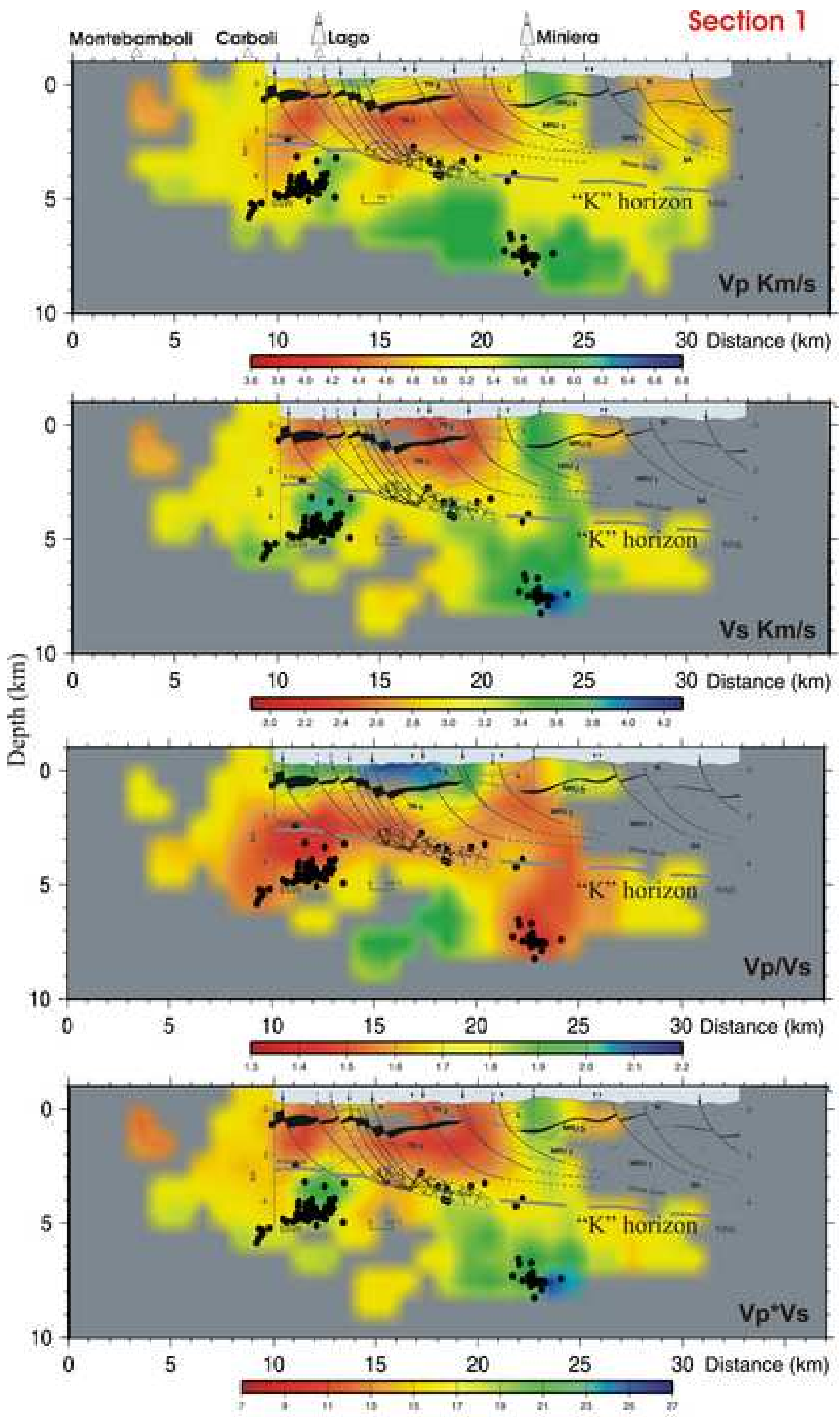

Figure 11 